\title{
Human Dental Microwear From Ohalo II (22,500-23,500 cal BP), Southern Levant
}

\author{
Patrick Mahoney* \\ Department of Archaeology, University of Sheffield, Sheffield S1 4ET, England
}

KEY WORDS late Upper Palaeolithic; hunter-gatherer; diet

\begin{abstract}
Dietary hardness and abrasiveness are inferred from human dental microwear at Ohalo II, a late Upper Palaeolithic site $(22,500-23,500$ cal BP) in the southern Levant. Casts of molar grinding facets from two human skeletons were examined with a scanning electron microscope. The size and frequency of microwear was measured, counted, and compared to four prehistoric human groups from successive chronological periods in the same region: pre-pottery Neolithic A, Chalcolithic (this study); Natufian, pre-pottery Neolithic B (Mahoney: Am J Phys Anthropol 130 (2006) 308-319). The Ohalo molars had a high frequency of long narrow scratches, and a few small pits, suggesting a tough abrasive diet that required more shearing rather than compressive force while chew-
\end{abstract}

The Upper Palaeolithic (40-10,000 BP) in the Levant included developments in technology, social organization, behavior, and economy (Bar Yosef, 2002). Some of these developments can be seen at Ohalo II, an archaeological site located on the shores of the Sea of Galilee that was occupied 23,500-22,500 cal BP (Nadel, 1990, 1991, 2001, 2003; Carmi and Segal, 1992; Nadel et al., 1995, 2001). Excavations at Ohalo II have revealed brush huts, hearths, and a human grave (Hershkovitz et al., 1995; Nadel and Werker, 1999). Tools included food processing equipment, while the abundant plant and animal remains have provided insights into the possible diet of the late Upper Palaeolithic occupants (Simmons and Nadel, 1998; Piperno et al., 2004; Weiss et al., 2004). Yet, little is known about dietary hardness and abrasiveness at this site, or for the late Upper Palaeolithic economy more generally. The aim in this study is to gain insights into these aspects of diet from microscopic marks (pits and scratches) preserved on the dental enamel of a human skeleton (Specimen No. H1) and an isolated human mandible (Specimen No. H2), both retrieved from Ohalo II (Nadel and Hershkovitz, 1991). Microwear from Ohalo will be compared with four human groups in the same region (Natufian, pre-pottery Neolithic A and B, Chalcolithic) representing successive chronological periods. It is expected that dietary similarities between the late Upper Palaeolithic hunter-gatherers from Ohalo and Epipalaeolithic Natufian hunter-gatherers will produce similar microwear, which differs from subsequent periods.

\section{BIOCULTURAL CONTEXT Material evidence for diet at Ohalo}

Exceptional preservation of plant and animal remains has provided clues about the late Upper Palaeolithic economy at Ohalo. Charred plant remains suggest that ing. These results imply that the diet of the two late Upper Palaeolithic hunter-gatherers did not focus on very hard foods. Aquatic foods with adherent contaminants, as well as grit from plant grinding tools seemed likely causal agents. The size of the pits and scratches on the Ohalo molars were most similar to microwear from the pre-pottery Neolithic A period, though they also compared well to the Chalcolithic period. These results contrasted with the larger pits and scratches from the Natufian hunter-gatherers and pre-pottery Neolithic B farmers, implying that there is no simple increase or decrease in dietary hardness and abrasiveness across the late Upper Palaeolithic to Chalcolithic development in the Southern Levant. Am J Phys Anthropol 132:489-500, 2007. @ 2007 Wiley-Liss, Inc.

the diet included small grained grasses such as brome (Bromus pseudobrachystachys/tigridis), as well as wild cereals such as barley (Hordeum spontaneum) and emmer wheat (Triticum dicoccoides) (Kislev et al., 1992, 2002; Weiss et al., 2004, 2005). Evidence from stone artefacts indicates that some plant foods were ground before consumption (Piperno et al., 2004). Animal foods included gazelle, deer, and waterfowl (Simmons and Nadel, 1998; Rabinovich, 2002), though the great abundance of bones from the Cyprinidae and Cichlidae families implies that fish were also an important dietary component (Zohar, 2002). Overall, the economy at the site appeared to be based on a combination of fishing, hunting, and gathering of a wide range of plant species on a year-round basis (Nadel et al., 2004).

\section{Diet-microwear relationships}

Microscopic pits and scratches form on enamel during chewing. These pits and scratches, known as dental microwear, are caused as hard particles (the comparative ability of a material to dent or scratch another material, as measured by the Mohs scale) are driven into (compression) or dragged between (shear) opposing enamel

Grant sponsors: AHRC United Kingdom; Council for British Research in the Levant.

*Correspondence to: Patrick Mahoney, Department of Archaeology, University of Sheffield, Northgate House, West Street, Sheffield S1 4ET, England. E-mail: p.mahoney@sheffield.ac.uk

Received 16 June 2006; accepted 9 November 2006.

DOI 10.1002/ajpa.20548

Published online 22 January 2007 in Wiley InterScience

(www.interscience.wiley.com). 
surfaces as the jaw moves through the chewing cycle. Two types of particle commonly ingested are thought to be hard enough to cause microwear. Silica bodies, phytoliths, are present in some plant leaves, stems, and seed coats. Phytoliths have a hardness that exceeds dental enamel (Mohs test of hardness: enamel $=4.5-5.0$; phytolith = 5.5-6.5) (Baker et al., 1959; Piperno, 1988). Quartz inclusions are present in some soils, and plantgrinding tools made from sandstone, limestone, and igneous rock. Such inclusions are also harder than enamel and therefore could cause microwear if present on food as contaminants (Moh's test of hardness: quartz $=7.0$ ) (Cook and Kirk, 1995; Pough, 1996). Tooth-on-tooth contact may be another cause of microwear (Every, 1974; Rensberger, 1978, 2000; Teaford and Walker, 1983, 1984; Teaford and Runestad, 1992; Pe'rez-Pe'rez et al., 2003).

Based on these causal agents, increases and decreases in compression and shear during chewing have been inferred from the frequency and size of microwear. Under a hypothesized model of microwear formation processes, a diet high in compression and low in shear should produce large and/or frequent pits (Gordon, 1982; Mahoney, $2006 a, b)$. Scratches should become longer as shear increases and narrower as compression decreases (Gordon, 1982; Mahoney, 2006a,b), though these hypothesized models assume equivalent physical properties for food items. Studies on extant species support some of these ideas. Harder diets produce larger microwear features (Teaford and Walker, 1984; Teaford and Oyen, 1989; Teaford and Runestad, 1992), which might sometimes reflect increases in compression as hard particles are driven deeper into enamel (e.g., Ryan, 1979). More folivorous species have longer microwear features than more frugivorous species (Teaford and Walker, 1984; Ungar et al., 2006), presumably because sometimes a diet rich in tough foods requires more shear as the mandible moves through the chewing cycle, thus producing more slicing actions and reducing the food. Another consistent correlation occurs as dietary abrasiveness increases, which generates more scratches (Walker et al., 1978; Covert and Kay, 1981; Teaford and Lytle, 1996).

It can be more difficult to interpret dental microwear from meat-eating populations. Consuming meat can produce either more or less microwear on the occlusal surface of teeth (e.g., Gordon, 1986; Molleson and Jones, 1991), though microwear from the buccal surface can produce a more consistent pattern (Puech 1976; Lalueza et al., 1996). Most probably, the variation in the occlusal surface microwear patterns reflects the variation in the underlying cause. Meat is unlikely to be hard enough to cause a scratch or a pit. A more likely causal agent for primates is adherent grit (e.g., Ungar and Spencer, 1999). For carnivores, the amount of bone consumed is also a significant causal agent (Van Valkenburgh et al., 1990). Alternatively, meat can be tough enough to require significant shearing force to cut or fracture it during chewing (e.g., Lucas and Peters, 2000), resulting in forceful tooth-on-tooth contact, and perhaps removing fragments of enamel.

Another way of interpreting microwear patterns is through the size of abrasive particles. Introducing larger particles into a diet can result in wider scratches (Ungar, 1992, 1994; Pastor, 1993), and larger pits (Teaford, 1993; Teaford et al., 2001). In this case, the underlying causal agent may be responsible for a change in microwear, rather than variations in compression or shear, though the two processes are not mutually exclusive.

\section{Dental microwear of hunter-gatherers}

A limited number of studies have examined quantitative microwear of the permanent molar occlusal surface from hunter-gatherers. Aspects of diet have been inferred from microwear in Mesolithic populations from Syria and northern Indian, and late Archaic and Natufian hunter-gatherers from, respectively, North America and northern Israel (Molleson and Jones, 1991; Molleson et al., 1993; Pastor, 1993; Schmidt, 2001; Mahoney, 2003, 2006a). Dietary inferences have also been gained from microwear studies of early Homo (Waddle, 1988; Ungar et al., 2006). To date, no study has examined permanent molar microwear from late Upper Palaeolithic huntergatherers in the Southern Levant.

\section{MATERIALS AND METHODS The Ohalo II sample}

The recovery of a relatively complete human skeleton (H1) and a human mandible (H2) dating to around ca. 23,000 cal BP from Ohalo II were important finds because human remains from the late Upper Palaeolithic in the southern Levant are extremely rare (Nadel, 1990, 1991; Nadel and Hershkovitz, 1991). The H1 skeleton was an adult male that had been buried in a shallow pit at the site. Insights have been gained into the local sequence of hominid evolution from H1 through morphological comparisons with specimens from other regions (Hershkovitz et al., 1993, 1995).

All molar teeth from $\mathrm{H} 1$ and $\mathrm{H} 2$ were replicated (see next). Tooth replicas were examined at $200 \times$ using a scanning electron microscope (SEM) to establish whether microwear was present. Teeth showing postmortem microwear were identified and excluded (see Teaford, 1988; King et al., 1999). Antemortem microwear was identified on M3 grinding facets from H1, and M3 grinding facets from $\mathrm{H} 2$.

\section{The comparative sample}

Four pre-historic human groups from successive archaeological periods in the southern Levant were selected: Natufian, pre-pottery Neolithic A (PPNA), prepottery Neolithic B (PPNB), Chalcolithic (Table 1; Fig. 1; see Appendix for a list of all specimens). Data for PPNA and Chalcolithic specimens were produced for this study. Data for Natufian and PPNB specimens were taken from Mahoney (2006a). All of the archaeological sites in the comparative sample are well-documented in the literature (Noy and Higgs, 1971; Lechevallier and Ronen, 1985; Hershkovitz et al., 1986; Hershkovitz and Gopher, 1988; Noy, 1989; Bar Yosef, 1991; Garfinkel, 1993; Perrot, 1993; Ronen and Lechevallier, 1993; Gal et al., 1997; Gopher, 1997; Valla et al., 1998; Gal et al., 1999; GoringMorris, 2000; Lev Tov et al., 2003).

Natufian hunter-gatherers exploited a diverse range of animal and plant foods from both sedentary and mobile settlements (Bar Yosef, 1998). Animal foods included mainly gazelle, and fish at sites bordering permanent lakes (Bar Yosef, 1993; Noy, 1993; Perrot, 1993; Martin, 1994). Plant foods included mainly wild cereals, some of which might have been ground with stone tools before consumption (Perrot, 1960, 1993; Stekelis and Yizraely, 1963; Noy et al., 1973; Hillman, 1984, 1985; Hopf and Bar Yosef, 1987; Henry, 1989; Bar Yosef, 1991, 1993; Noy, 1993; Willcox, 1999). 
TABLE 1. The comparative sample

\begin{tabular}{lclr}
\hline \multicolumn{1}{c}{ Period } & Date (bp) & \multicolumn{1}{c}{ Site } & $n=91$ \\
\hline Natufian $^{1}$ & $12,500-10,000$ & Hayonim Cave & 16 \\
& & Ein Mallaha & 8 \\
& & Nahal Oren & 4 \\
& & Rakefet & 1 \\
PPNA $^{2}$ & $10,300-9,300$ & Hatoula & 9 \\
& & Netiv Hagdud & 3 \\
PPNB $^{1}$ & $9,400-8,100$ & Kfar Hahoresh & 21 \\
& & Yiftahel & 3 \\
& & Horvat Galil & 2 \\
Chalcolithic $^{2}$ & $6,300-5,300$ & Peqi'in & 24 \\
\hline
\end{tabular}

${ }^{1}$ Mahoney (2006a).

2 This study.

Material remains from PPNA Sultanian sites, one of three PPNA archaeological cultures distributed throughout the Levant, (the others being Khiamian and Harifian), suggest an increasingly sedentary lifestyle with a broad spectrum economy (Martin, 1994; Bar Yosef, 1998; Willcox, 1999). At the PPNA sites in this study, abundant remains of fish, molluscs, crab, water mole, and avifauna, indicate aquatic foods were an important dietary component (Bar Yosef et al., 1991; Ronen and Lechevallier, 1993). At other Sultanian sites, barley, wheat, and rye may have been cultivated, though this is not accepted unequivocally (Hopf, 1983; Van Zeist and Bakker-Heeres, 1984; Kislev et al., 1986; Willcox, 1998, 1999).

The PPNB economy was based on hunting and farming (e.g., Garfinkel, 1987). Animal foods in the study area included mainly gazelle, while the plant foods included pulses and cereals, some of which may have been cultivated and prepared for consumption using the large plant grinding tools that are a characteristic of the early Neolithic people (e.g., Wright, 1993; Gopher, 1997).

Settlements in the Chalcolithic period included permanent villages practicing a mixed farming economy (Gonen, 1992). Caves such as Peqiin were used as local or regional burial grounds (Goldberg and Rosen, 1987; Gal et al., 1997, 1999; Frankel et al., 2001; Nadar and Eshed, 2001). Domesticated produce included cereals, sheep, goat, pig, and fruit trees (Zohary and Spiegel-Roy, 1975; Horwitz and Tchernov, 1989; Zohary and Hopf, 1993; Grigson, 1995; Smith and Sabari, 1995; Agelarakis et al., 1998; Kahila and Smith, 2001; Zagerson and Smith, 2002; Lev-Tov et al., 2003). Technological differences with the preceding early Neolithic periods included the use of ceramic cooking utensils (Shalev, 1994; Levy, 1995; Golden et al., 2001).

\section{Casting and imaging procedure}

Standard procedures were followed (e.g., Nystrom et al., 2004; Ungar et al., 2006). Contaminants were removed from the occlusal surface of each molar using ethanol and cotton wool. An impression of the occlusal surface was taken using a rubber-based, addition-curing silicone (Coltène; President Jet, lightbody). Grinding facets (Maier and Schneck, 1982) were excised from each impression using a scalpel, and surrounded with Coltène President Putty to create a depression. A cast of the facet was produced using an epoxy resin (Araldite MY 753, hardener HY 956, CibaGeigy). Each cast was mounted on an aluminium stub after its base had been coated with an electrode paint (Electrodag $1415 \mathrm{M}$ ). The stub was placed into a sputter coating unit (EMSCOPE; SC500) for $3 \mathrm{~min}$, and coated with $20 \mathrm{~nm}$ of gold-paladium. Digitized micrographs were taken

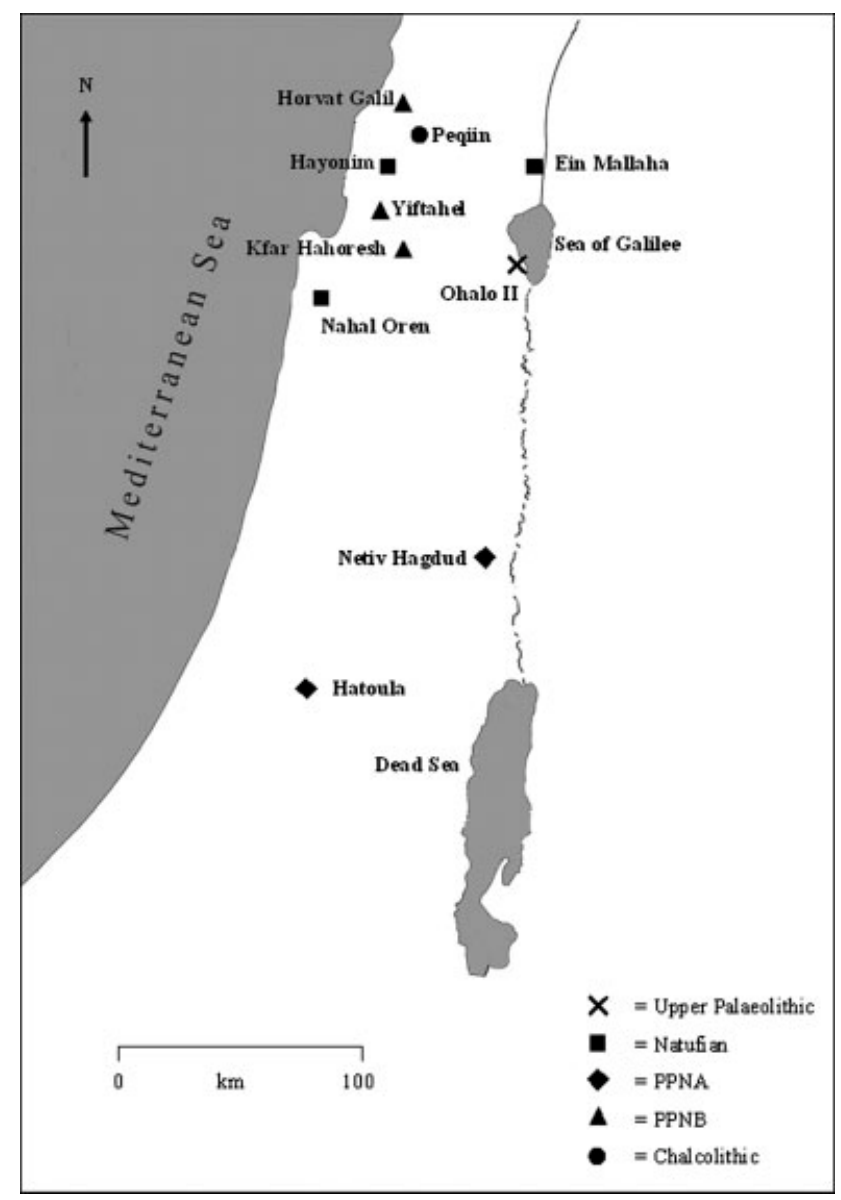

Fig. 1. Map of Natufian, PPNA, PPNB, and Chalcolithic sites in the southern Levant.

at a magnification of $500 \times$, using a SEM (CAMSCAN) at the Sorby Centre for Electron Microscopy and Microanalysis, University of Sheffield. The CAMSCAN was operated in the secondary electron emission mode, with a spot size (resolution) of 3.0 and an accelerating voltage of $15 \mathrm{kV}$. Dental casts were oriented perpendicularly to the primary beam (tilt angle $0^{\circ}$ ). Each digitized micrograph $(1004 \times$ 744 pixels) represented $\sim 0.04 \mathrm{~mm}^{2}$ of the tooth surface.

Microwear can vary between the bottom (i.e. towards the central fossa) and top of facet 9, and this can influence comparisons between samples (Mahoney, 2006a,c). Therefore, a single digitized micrograph was taken from the bottom of facet 9 from the $M_{2}$ of each specimen in the comparative sample to try and reduce microwear variation due to facet location.

For the Ohalo sample, four adjacent micrographs were taken from the H1 M3, and the H2 M3. Microwear patterns do not vary between grinding facets on human second and third molars, so comparing the data for third molars from Ohalo with second molars from the comparative sample should not be problematic (Mahoney, 2003, $2006 b, c)$. However, including teeth from both the mandible and maxilla might affect the averaged dental microwear parameters for the Ohalo individuals.

\section{Data collection}

Pits and scratches were measured and counted using a semi-automated image analysis computer program 
TABLE 2. Microwear measurements in $\mu \mathrm{m}$ for the comparative sample grouped by period

\begin{tabular}{|c|c|c|c|c|c|c|c|c|c|c|}
\hline \multirow[b]{2}{*}{ Period } & \multicolumn{2}{|c|}{$\%$ Pits } & \multicolumn{2}{|c|}{ Pit length } & \multicolumn{2}{|c|}{ Pit width } & \multicolumn{2}{|c|}{ Scratch length } & \multicolumn{2}{|c|}{$\begin{array}{l}\text { Scratch } \\
\text { breadth }\end{array}$} \\
\hline & $X$ & s.d. & $X$ & s.d. & $X$ & s.d. & $X$ & s.d. & $X$ & s.d. \\
\hline Natufian $^{1}(n=29)$ & 50.10 & 9.84 & 4.61 & 1.13 & 2.30 & 0.66 & 23.80 & 8.56 & 1.41 & 0.27 \\
\hline $\operatorname{PPNA}^{2}(n=12)$ & 36.52 & 13.86 & 2.36 & 0.40 & 1.42 & 0.21 & 41.89 & 16.26 & 0.87 & 0.19 \\
\hline $\operatorname{PPNB}^{1}(n=26)$ & 47.17 & 15.20 & 5.27 & 0.88 & 2.62 & 0.61 & 26.69 & 8.87 & 1.60 & 0.23 \\
\hline Chalcolithic $^{2}(n=24)$ & 35.30 & 11.44 & 2.72 & 0.51 & 1.51 & 0.28 & 44.51 & 12.91 & 0.86 & 0.16 \\
\hline
\end{tabular}

${ }^{1}$ Mahoney (2006a).

2 This study.

$X$, mean; s.d., standard deviation.

TABLE 3. Microwear measurements in $\mu \mathrm{m}$ for the comparative sample subdivided by site

\begin{tabular}{|c|c|c|c|c|c|c|c|c|c|c|}
\hline \multirow[b]{2}{*}{ Site } & \multicolumn{2}{|c|}{$\%$ Pits } & \multicolumn{2}{|c|}{ Pit length } & \multicolumn{2}{|c|}{ Pit width } & \multicolumn{2}{|c|}{ Scratch length } & \multicolumn{2}{|c|}{$\begin{array}{l}\text { Scratch } \\
\text { breadth }\end{array}$} \\
\hline & $X$ & s.d. & $X$ & s.d. & $X$ & $\overline{\text { s.d. }}$ & $X$ & s.d. & $X$ & s.d. \\
\hline Hayonim & 47.16 & 8.53 & 5.20 & 1.18 & 2.65 & 0.70 & 27.88 & 9.12 & 1.48 & 0.31 \\
\hline Ein Mallaha & 52.55 & 12.68 & 3.92 & 0.21 & 1.83 & 0.14 & 17.42 & 3.69 & 1.28 & 0.11 \\
\hline Nahal Oren & 56.34 & 6.99 & 3.71 & 0.68 & 1.87 & 0.27 & 20.51 & 4.92 & 1.37 & 0.28 \\
\hline Rakefet & 52.63 & - & 4.18 & - & 2.23 & - & 22.78 & - & 1.43 & - \\
\hline Hatoula & 41.49 & 10.06 & 2.38 & 0.45 & 1.43 & 0.20 & 41.11 & 16.34 & 0.89 & 0.21 \\
\hline Netiv Hagdud & 21.60 & 14.37 & 2.30 & 0.28 & 1.40 & 0.29 & 44.21 & 19.41 & 0.79 & 0.13 \\
\hline Kfar Hahoresh & 44.50 & 14.81 & 5.19 & 0.94 & 2.64 & 0.62 & 27.95 & 9.26 & 1.59 & 0.23 \\
\hline Yiftahel & 65.46 & 2.02 & 5.97 & 0.02 & 2.26 & 0.35 & 20.54 & 4.63 & 1.50 & 0.15 \\
\hline Horvat Galil & 47.76 & 15.20 & 5.09 & 0.18 & 2.99 & 0.75 & 22.69 & 5.51 & 1.87 & 0.19 \\
\hline Peqiin & 35.30 & 11.44 & 2.72 & 0.51 & 1.51 & 0.28 & 44.51 & 12.91 & 0.86 & 0.16 \\
\hline
\end{tabular}

(Microware version 3; Ungar, 1997). A resolution of 0.254 microns per pixel (DPI 200) was selected. Five variables representing the size and frequency of microwear were created from each micrograph: percent pits, mean length and width of pits, and mean length and breadth of scratches. A 4:1 length-to-width ratio was used to distinguish between pits and scratches. All micrographs were recorded and a mean value produced for each individual.

All of the data included in this study was produced and recorded by a single observer (the author) using the same SEM, that was set to the same KV, resolution, tilt angle, and distance from the SEM primary beam, thus eliminating inter-observer error and variation due to different quantification protocols (e.g., Grine et al., 2002). Microware version 3 (Ungar, 1997) was used throughout. Following Ungar et al. (2006) and Organ et al. (2005), the microwear measurements for each individual in the comparative sample are included in Appendix, so that this study can contribute to the growing body of microwear data that is available for others to analyse. Microwear measurements for the Ohalo specimens are presented in the tables.

\section{Analyses}

The analyses involved two stages. The aim in the first stage was to identify microwear variation within the comparative sample, when grouped by archaeological period. Significant differences were sought between the groups using a one-factor between-subjects analysis of variance (ANOVA). The data failed one test assumption (that the groups come from populations with equal variances). The data were either log- or square root-transformed (percent pits arcsine-transformed (Zar, 1999; Tabachnick and Fidell, 2001) and the test assumption was satisfied. Multiple comparisons were conducted to
TABLE 4. Comparisons between the comparative sample grouped by period: individual ANOVAs

\begin{tabular}{lccc}
\hline \multicolumn{1}{c}{ Variable } & df & $F$ & $P$ \\
\hline \%Pits & 3 & 8.046 & 0.000 \\
Pit length & 3 & 81.776 & 0.000 \\
Pit width & 3 & 36.201 & 0.000 \\
Scratch length & 3 & 20.827 & 0.000 \\
Scratch breadth & 3 & 71.584 & 0.000 \\
\hline
\end{tabular}

identify homgenous subsets using Tukey's post hoc test. ${ }^{1}$ Following this, a discriminant function analysis (DFA) was conducted using the (significant) microwear variables (for a DFA methodology see Mahoney, 2006a). A DFA was chosen to evaluate how well the significant microwear patterns characterized the comparative sample, and to assess how each contributed to the variation between the archaeological periods. All statistical tests were conducted using SPSS (version 12.0.1).

The aim in the second stage was to identify microwear similarities between the Ohalo specimens and 1) the comparative sample when grouped by archaeological period, and 2) the comparative sample subdivided by archaeological site. The Ohalo specimens were entered into the DFA, (constructed previously on the comparative sample), as ungrouped variables. The aim of the DFA was to characterize the microwear from the Ohalo specimens by placing them into one of the archaeological periods (i.e. Natufian, PPNA, PPNB, Chalcolithic). Following this, a Hierarchical Cluster Analyses (HCA) was conducted to identify microwear similarities between Ohalo

\footnotetext{
${ }^{1}$ Significant microwear differences between the archaeological sites were not sought because five of the sites in the comparative sample contained very small sample sizes, which can be seen in Table 1 . Instead, a HCA was used in the next stage of the analyses.
} 
TABLE 5. Comparisons between the comparative sample grouped by period: homogenous subsets ${ }^{1}$

\begin{tabular}{|c|c|c|c|c|c|c|c|c|c|c|}
\hline \multirow[b]{3}{*}{ Subsets } & \multicolumn{6}{|c|}{ Pit } & \multicolumn{4}{|c|}{ Scratch } \\
\hline & \multicolumn{2}{|c|}{$\%$} & \multicolumn{2}{|c|}{ Length } & \multicolumn{2}{|c|}{ Width } & \multicolumn{2}{|c|}{ Length } & \multicolumn{2}{|c|}{ Breadth } \\
\hline & 1 & 2 & 1 & 2 & 1 & 2 & 1 & 2 & 1 & 2 \\
\hline Natufian & 0.786 & & 0.652 & & 0.346 & & 1.350 & & 0.142 & \\
\hline PPNB & $0.755^{2}$ & & 0.716 & & 0.408 & & 1.406 & & 0.201 & \\
\hline PPNA & & 0.638 & & 0.366 & & 0.150 & & 1.587 & & -0.068 \\
\hline Chalcolithic & & 0.632 & & 0.429 & & 0.171 & & 1.631 & & -0.068 \\
\hline
\end{tabular}

${ }^{1}$ Results of the Tukey HSD tests, which show homogenous subsets within the groups.

${ }^{2}$ In this subset the PPNB is not significantly different from the PPNA.

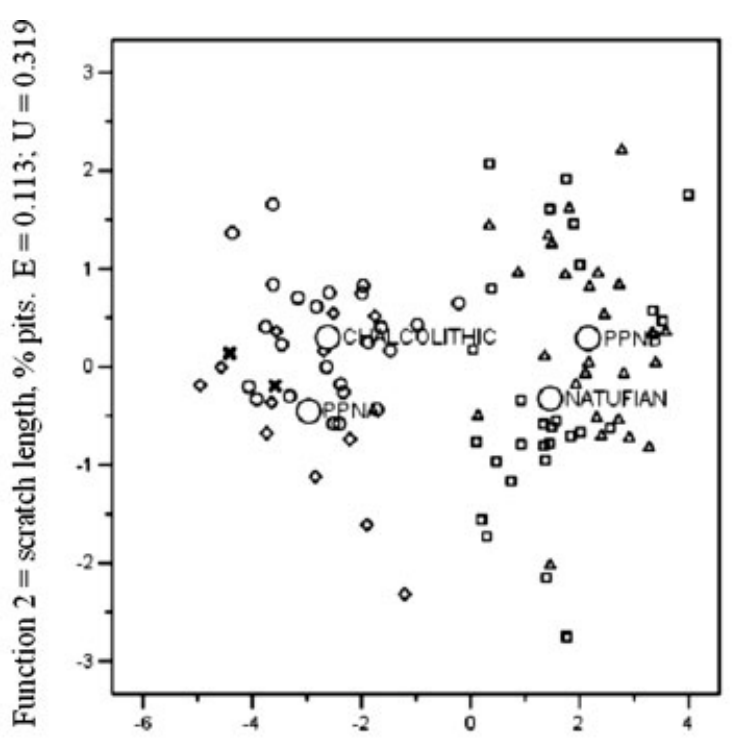

Function $1=$ pit length/ width, scratch width. $E=5.193 ; \mathrm{U}=0.916$

Fig. 2. Plot of the Discriminant Function Analysis. $\square=$ Natufian; $\diamond=$ PPNA, $\triangle=$ PPNB, $\bigcirc=$ Chalcolithic, $\times=$ OhaloII. $\mathrm{E}=$ Eigenvalue, $\mathrm{U}=$ canonical correlation. The large circles represent the discriminant scores for the group means (first function: Natufian $=1.459$, PPNA $=-2.963$, PPNB $=2.154$, Chalcolithic $=$ -2.615 ; second fucntion: Natufian $=-0.323$, PPNA $=-0.454$, $\mathrm{PPNB}=0.293$, Chalcolithic $=0.299$ ).

II and the comparative sample when subdivided by archaeological site. A HCA is an objective methodology for quantifying and comparing a data set, but it is not an inferential statistical procedure.

\section{RESULTS}

\section{The comparative sample}

Descriptive statistics for the comparative sample are shown in Table 2 (grouped by archaeological period) and Table 3 (subdivided by archaeological site). Inferential statistics are given in Table 4 (individual ANOVAs) and Table 5 (homogenous subsets). A plot of the DFA is illustrated by Figure 2 .

Individual ANOVAs show that pit and scratch size varied between the groups. The larger pits and scratches of the Natufians and PPNB farmers formed homgenous subsets, which differed from the smaller pits and scratches of the Chalcoltihic and PPNA people, who also formed homogenous subsets. The $\mathrm{F}$ value indicates that pit frequency was less able to distinguish between the groups.
Two discriminant functions were calculated with an $X^{2}$ (15) of $168.112, P=0.000$ (first function), and $X^{2}$ (8) of $12.215, P=0.142$ (second function), which indicated that the mean of the first function only was not equal across groups. The structure matrix showed that the first function was created from pit length, scratch width, and pit width $(0.733,0.687,0.487$, respectively) and accounted for $97.2 \%$ of the total variance. The second function was created from scratch length and \% pits $(0.808,-0.416$, respectively), and accounted for $2.8 \%$ of the variance. The high proportion of individuals correctly classified (Natufian $=69.0 \% ;$ PPNA $=75.0 \% ;$ PPNB $=84.6 \%$; Chalcolithic $79.2 \%$; Overall $=76.9 \%$ ) indicated that the larger pits and wider scratches during the Natufian and PPNB period was a good combination of variables for emphasizing differences with the smaller pits and narrower scratches of the Chalcolithic and PPNA periods. This interpretation was supported by the high measures of variance for the first function (eigenvalue $=5.193$; canonical correlation $=0.916$ ), and the plot of the discriminant scores taken from each individual, which illustrated the good visual separation between the Natufian and PPNB period, when compared with the PPNA and Chalcolithic period.

\section{The Ohalo II sample}

Descriptive statistics for the Ohalo II sample are shown in Table 6. The position of the Ohalo specimens in the plot of the DFA is illustrated by Figure 2. The results of the HCA are shown in Figure 3A (\% pits), Figure 3B (pit size), and Figure 3C (scratch size). Representative micrographs are shown in Figure 4.

When $\mathrm{OH} 1$ and $\mathrm{OH} 2$ were entered into the DFA as ungrouped variables, they received discriminant scores of -4.407 and -3.581 (respectively for the first function) and 0.139 and -0.190 (respectively for the second function; see Fig. 2). These scores categorized both specimens as PPNA.

There are three distinct clusters for the percentage of pits. Ohalo II and Netiv Hagdud, the sites with the lowest percentage of dental pits, and therefore the highest percentage of scratches, separate from all other archaeological sites. Two other clusters separate sites with frequent dental pits (Ein Mallaha, Rakefet, Nahal Oren, and Yiftahel), from sites with comparatively fewer pits (Kfar Hahoresh, Horvat Galil, Hayonim, Hatoula, and Peqiin). These results show why the percentage of pits was a comparatively weak variable for separating the archaeological periods, both in the subsets formed in the ANOVAs (Table 5) and the DFA (see Fig. 2). For instance, the PPNA site Hatoula is clustered with Natufian, PPNB and Chalcolithic sites, while the other PPNA site clusters with Ohalo II. 
TABLE 6. Microwear measurements in $\mu \mathrm{m}$ for Ohalo II

\begin{tabular}{|c|c|c|c|c|c|c|c|c|c|c|}
\hline \multirow[b]{2}{*}{ Ohalo II } & \multicolumn{2}{|c|}{$\%$ Pits } & \multicolumn{2}{|c|}{ Pit length } & \multicolumn{2}{|c|}{ Pit width } & \multicolumn{2}{|c|}{ Scratch length } & \multicolumn{2}{|c|}{ Scratch breadth } \\
\hline & $X$ & s.d. & $X$ & $\overline{\text { s.d. }}$ & $X$ & s.d. & $X$ & s.d. & $X$ & s.d. \\
\hline $\mathrm{H} 1^{1}$ & 22.69 & - & 1.78 & 0.98 & 0.88 & 0.33 & 40.25 & 21.66 & 0.73 & 0.24 \\
\hline $\mathrm{H} 1^{1}$ & 17.95 & - & 2.03 & 1.05 & 1.17 & 0.27 & 51.61 & 13.24 & 0.68 & 0.19 \\
\hline $\mathrm{H} 1^{1}$ & 10.32 & - & 2.16 & 1.18 & 1.04 & 0.24 & 47.99 & 17.11 & 0.69 & 0.21 \\
\hline $\mathrm{H} 1^{1}$ & 26.67 & - & 2.23 & 0.61 & 1.36 & 0.28 & 58.31 & 18.43 & 0.80 & 0.23 \\
\hline Mean $^{2}$ & 19.40 & 7.02 & 2.05 & 0.95 & 1.11 & 0.28 & 49.54 & 17.61 & 0.72 & 0.21 \\
\hline $\mathrm{H} 2^{3}$ & 20.90 & - & 2.25 & 0.56 & 1.50 & 0.34 & 34.15 & 25.61 & 1.07 & 0.45 \\
\hline $\mathrm{H} 2^{3}$ & 13.97 & - & 2.31 & 0.94 & 1.23 & 0.42 & 41.27 & 19.33 & 0.77 & 0.31 \\
\hline $\mathrm{H} 2^{3}$ & 18.13 & - & 2.18 & 0.64 & 1.44 & 0.55 & 48.71 & 21.01 & 0.68 & 0.34 \\
\hline $\mathrm{H} 2^{3}$ & 21.30 & - & 2.59 & 0.42 & 1.52 & 0.43 & 45.08 & 15.66 & 0.69 & 0.21 \\
\hline Mean $^{2}$ & 18.57 & 3.37 & 2.33 & 0.64 & 1.42 & 0.43 & 42.30 & 20.40 & 0.80 & 0.32 \\
\hline Overall $^{4}$ & 18.99 & 5.12 & 2.19 & 0.79 & 1.26 & 0.35 & 45.92 & 19.00 & 0.76 & 0.27 \\
\hline
\end{tabular}

${ }^{1}$ Measurements from four micrographs and a mean value are given for grinding facets on M3.

2 There is some variation between the four micrographs from each Ohalo specimen compared with the mean microwear measurements. Based on the sample sizes, it is not possible to say weather the microwear patterns differ significantly between the micrographs.

${ }^{3}$ Measurements from four micrographs and a mean value are given for grinding facets on M3.

${ }^{4}$ A mean of the two means.

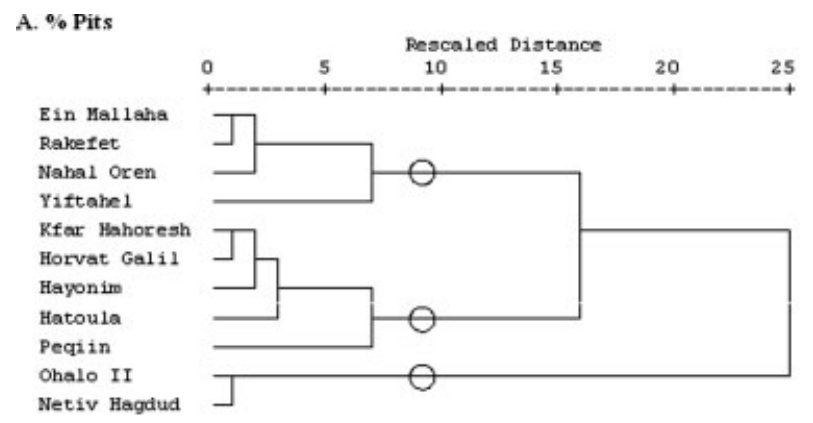

B. Pit size (length, width)

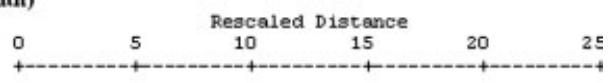

Hayonim Kfar Hahoresh Horvat Gali1 Yiftahe 1 Ein Nallaha Nahal Oren Rakefet Hatoula Netiv Hagdud Ohalo II Peqi in

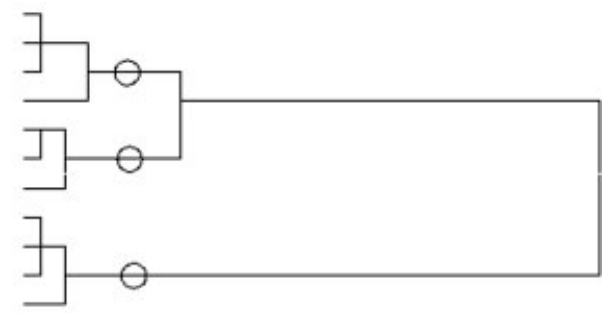

C. Saratch size (length, width)$$
0
$$

5 caled Distan

Ohalo II Netiv Hagdud Hatoula Peqi in Nahal Oren Yiftahe 1 Raketet Ein Mallaha Hayonim Kfar Hahoresh Horvat Galil

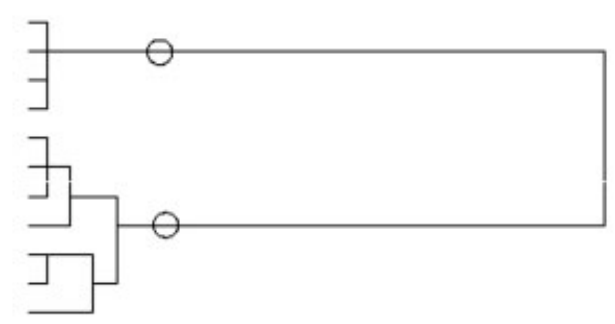

Fig. 3. Hierarchial cluster analysis for all sites. Each circle indentifies a cluster. Deciding where to cut the dendogram is subjective.

There are three clusters for pit size. The sites with the smallest dental pits, Ohalo II, the two PPNA sites Netiv Hagdud and Hatoula, and the Chalcolithic site Peqiin, separate from all other sites. This clustering is supported by the results of the homogenous subsets formed in the ANOVAs (Table 5), which separated the smaller dental pits of the PPNA and Chalcolithic sites, from the larger dental pits of the Natufian and PPNB sites. This clustering is also supported by the results of the DFA (see Fig. 2), which separated these sites, as well as placing Ohalo II with the PPNA sites. Another cluster (Ein Mallaha, Nahal Oren and Rakefet) merges with the remaining cluster (Hayonim, Kefar Hahoresh, Horvat Galil and Yiftahel) at a lower level of similarity.

There are two distinct clusters for scratch size. Sites with long narrow scratches (Ohalo II, Netiv Hagdud, Hatoula, and Peqiin), separate from all of the remaining sites.

\section{DISCUSSION \\ The comparative sample}

The large pits and wide scratches on the molars from the Natufian hunter-gatherers and PPNB farmers suggest a comparatively hard diet that emphasized compressive forces (Tables 2 and 5). Plant foods prepared for consumption using grinding stones may have contributed to the harder diet by contaminating food with quartz particles (Mahoney, 2006a). In contrast, the small pits and narrow scratches of the PPNA and Chalcolithic people suggest a softer diet, which is likely due to different factors in each period (Tables 2 and 5). Towards the end of the Natufian period and early PPNA a climatic change led to a cold-dry period, which may have limited some food sources (Baruch and Bottema, 1991; Hillman, 1996; Bar Yosef, 1998). For instance, while plant foods are present at PPNA sites, they are more frequent at some of the PPNB sites (Kislev, 1985; Garfinkel, 1987), implying that the PPNA diet might have been less contaminated by hard stone dust from plant grinding tools.

Different sized contaminants may have contributed to the different microwear signatures (e.g., Ungar, 1992, 1994; Pastor, 1993; Lalueza et al., 1996; Daegling and Grine, 1999). Remains of fish, molluscs, crab, water mole, and avifauna were present at the PPNA sites, implying that aquatic foods were an important dietary component (Bar Yosef et al., 1991; Ronen and Lechevallier, 1993). The diet of the Natufians and PPNB farmers was also rich in meat from land animals (i.e. gazelle). If 


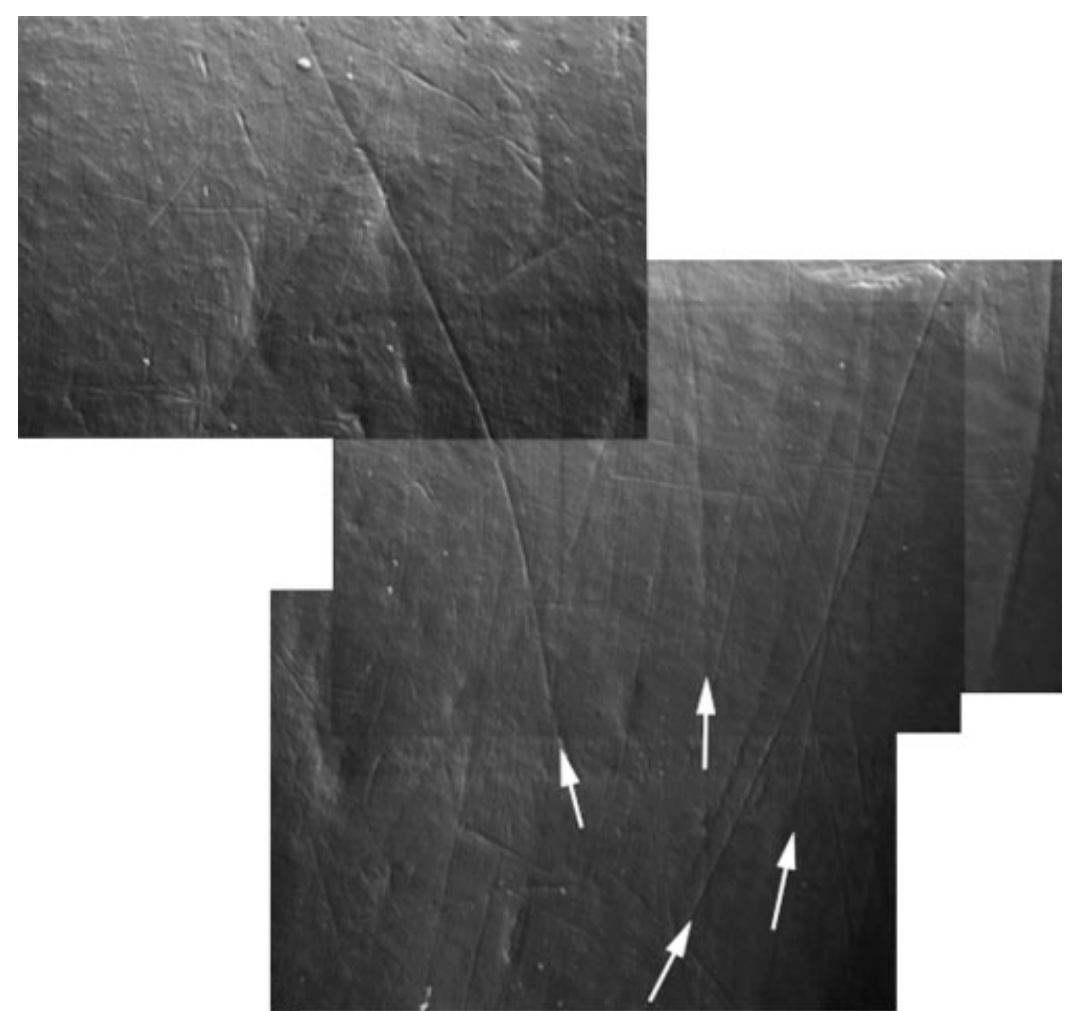

Fig. 4. Microwear on an M3 grinding facet from H1. Micrographs illustrating the frequent narrow dental scratches on the OhaloII molars. Arrows indicate scratches.

fine particles such as clay grains from inland water sources adhered to the aquatic foods and large grained particles from the quartz-rich terra rossa and rendzina soils (Karmon, 1971; Goldberg, 1979; Dewdney, 1987) contaminated meat from land sources, then differences in pit and scratch size might be expected, similar to the situation proposed for north American hunter-gatherers (e.g., Teaford et al., 2001).

Some support for this idea is provided by the Natufian site with the narrowest pits and scratches, Ein Mallaha, where, just like the PPNA sites, the faunal remains included fish (Perrot, 1993; see also Table 3). Neither is it likely, in this case, that the scratches and pits should be attributed to different underlying causes (e.g., Teaford, 1993). Across the entire sample as a whole the strong positive correlation between scratch and pit width (Pearson's $R=0.818, P=0.000$ ) suggests that both microwear features reflect similar rather than different causal agents.

Food preparation technology is a likely contributing factor to the small pits of the Chalcolithic people. Increased use of ceramic cooking utensils is thought to influence the physical composition of food, producing a softer diet, which requires a reduction in bite force and consequent change in microwear (e.g. Molleson et al., 1993).

\section{Similarities between Ohalo II and the comparative sample}

The Ohalo molars had frequent long narrow scratches, and a few small pits. Overall, this microwear pattern was most similar to the PPNA people, though it also compared well to the Chalcolithic people (see Fig. 2). These results suggest similarities in dietary hardness and abrasiveness between the late Upper Palaeolithic hunter-gatherers, the PPNA, and Chalcolithic people, which contrasts with the microwear signature from the Natufian hunter-gatherers and PPNB farmers. This suggests that there may be no simple increase or decrease in dietary hardness and abrasiveness across the late Upper Palaeolithic to Chalcolithic development in the Southern Levant.

The frequent long scratches on the Ohalo molars suggests a tough abrasive diet that emphasized shearing 
forces, rather than a hard brittle diet that required high compressive forces. This idea compares well to the material remains from the site, which included plant foods, a grinding stone, and remains of aquatic foods (Zohar, 2002; Piperno et al., 2004; Weiss et al., 2004). A diet rich in plant foods can generate long microwear features (e.g., Teaford and Walker, 1984; Lalueza et al., 1996; Ungar et al., 2006), while an increased ingestion of hard dust from grinding stones can produce more microwear (e.g., Teaford and Lytle, 1996). At Ohalo, it seems likely that stone ground plants formed a component of the diet (Piperno et al., 2004). Therefore, hard stone dust could have acted as a microwear causal agent, similar to the situation proposed for the Natufians and PPNB farmers. However, unlike the Natufians or PPNB farmers, the few small pits on the Ohalo molars suggest a diet that did not require great compressive forces, and this is also suggested by the narrow scratches. Instead, perhaps the abundance of aquatic foods in the faunal remains at the site (Zohar, 2002) also contributed to the microwear. Assuming that the previous hypothesized relationship between microwear causal agents and meat is correct, the comparatively smaller clay particles from the Sea of Galilee (Tsatskin and Nadel, 2003) could have contaminated the aquatic foods at Ohalo with fine abrasives, thus contributing towards a fine microwear signature (i.e. a high proportion of narrow scratches). This is also suggested by the similarity in the microwear patterns from the late Upper Palaeolithic hunter-gatherers and the PPNA sites, particularly Netiv Hagdud (see Fig. 3), where both aquatic foods, and ground plants, seem to have been dietary components.

\section{CONCLUSIONS}

The Ohalo molars had a high frequency of long narrow scratches and a few small pits. It was inferred from the microwear that the late Upper Palaeolithic hunter-gatherers consumed a tough abrasive diet that emphasized shearing rather than compressive forces while chewing. Grit from stone ground plant foods and contaminants adhering to aquatic foods seemed likely microwear causal agents.

It was expected that dietary similarities between the late Upper Palaeolithic hunter-gatherers and the Natufian hunter-gatherers from the same region would produce similar microwear signatures. It was found that the size of the pits and scratches on the Ohalo molars compared well to microwear from the PPNA and Chalcolithic people, rather than the Natufians, or the PPNB farmers. This implies that there is no simple increase or decrease in dietary hardness and abrasiveness across the late Upper Palaeolithic to Chalcolithic development in the Southern Levant.

APPENDIX. Phase II facet microwear descriptive statistics

\begin{tabular}{|c|c|c|c|c|c|c|}
\hline \multirow[b]{2}{*}{ Period } & \multirow[b]{2}{*}{ Site $^{1}$} & \multicolumn{3}{|c|}{ Pit } & \multicolumn{2}{|c|}{ Scratch } \\
\hline & & $\%$ & Length & Width & Length & Breadth \\
\hline Natufian & Hayonim & 45.87 & 5.39 & 2.98 & 34.97 & 1.66 \\
\hline Natufian & Hayonim & 46.00 & 5.83 & 3.29 & 16.87 & 1.45 \\
\hline Natufian & Hayonim & 32.72 & 6.55 & 3.48 & 37.82 & 1.40 \\
\hline Natufian & Hayonim & 50.00 & 4.42 & 3.49 & 27.44 & 1.89 \\
\hline Natufian & Hayonim & 39.06 & 5.61 & 2.72 & 36.68 & 1.60 \\
\hline Natufian & Hayonim & 41.71 & 5.15 & 2.21 & 42.22 & 1.09 \\
\hline Natufian & Hayonim & 54.48 & 4.74 & 1.98 & 26.82 & 0.96 \\
\hline Natufian & Hayonim & 56.18 & 3.93 & 2.93 & 12.63 & 1.46 \\
\hline Natufian & Hayonim & 43.55 & 4.28 & 2.23 & 23.54 & 1.30 \\
\hline Natufian & Hayonim & 63.48 & 4.37 & 1.72 & 17.67 & 1.21 \\
\hline Natufian & Hayonim & 50.58 & 3.64 & 1.91 & 21.41 & 1.23 \\
\hline Natufian & Hayonim & 48.61 & 3.46 & 1.28 & 29.04 & 1.21 \\
\hline Natufian & Hayonim & 56.30 & 6.53 & 2.91 & 21.39 & 1.75 \\
\hline Natufian & Hayonim & 50.44 & 7.53 & 2.77 & 28.57 & 1.97 \\
\hline Natufian & Hayonim & 31.48 & 6.67 & 3.73 & 25.58 & 2.01 \\
\hline Natufian & Hayonim & 44.15 & 5.21 & 2.83 & 43.58 & 1.56 \\
\hline Natufian & Ein Mallaha & 51.77 & 3.91 & 2.03 & 18.23 & 1.18 \\
\hline Natufian & Ein Mallaha & 44.29 & 4.24 & 1.80 & 18.26 & 1.34 \\
\hline Natufian & Ein Mallaha & 66.00 & 3.66 & 1.68 & 12.78 & 1.25 \\
\hline Natufian & Ein Mallaha & 47.41 & 4.24 & 1.95 & 19.35 & 1.40 \\
\hline Natufian & Ein Mallaha & 32.38 & 3.78 & 1.67 & 20.12 & 1.12 \\
\hline Natufian & Ein Mallaha & 56.95 & 3.82 & 1.87 & 20.91 & 1.48 \\
\hline Natufian & Ein Mallaha & 48.79 & 3.98 & 1.71 & 19.14 & 1.24 \\
\hline Natufian & Ein Mallaha & 72.81 & 3.76 & 1.97 & 10.60 & 1.26 \\
\hline Natufian & Nahal Oren & 63.33 & 4.65 & 2.21 & 18.02 & 1.31 \\
\hline Natufian & Nahal Oren & 47.77 & 3.51 & 1.65 & 16.20 & 1.07 \\
\hline Natufian & Nahal Oren & 53.75 & 3.00 & 1.66 & 20.41 & 1.36 \\
\hline Natufian & Nahal Oren & 60.54 & 3.70 & 1.98 & 27.44 & 1.76 \\
\hline Natufian & Rakefet & 52.63 & 4.18 & 2.23 & 22.78 & 1.43 \\
\hline PPNA & Hatula & 54.48 & 2.51 & 1.52 & 18.44 & 0.98 \\
\hline PPNA & Hatula & 47.80 & 2.77 & 1.74 & 20.91 & 0.78 \\
\hline PPNA & Hatula & 46.90 & 2.69 & 1.49 & 39.06 & 0.76 \\
\hline PPNA & Hatula & 25.80 & 1.72 & 1.20 & 59.13 & 0.75 \\
\hline PPNA & Hatula & 51.40 & 1.88 & 1.26 & 51.25 & 0.86 \\
\hline PPNA & Hatula & 39.40 & 1.88 & 1.32 & 47.00 & 0.87 \\
\hline
\end{tabular}


APPENDIX (Continued)

\begin{tabular}{|c|c|c|c|c|c|c|}
\hline \multirow[b]{2}{*}{ Period } & \multirow[b]{2}{*}{ Site $^{1}$} & \multicolumn{3}{|c|}{ Pit } & \multicolumn{2}{|c|}{ Scratch } \\
\hline & & $\%$ & Length & $\overline{\text { Width }}$ & Length & Breadth \\
\hline PPNA & Hatula & 40.40 & 2.92 & 1.77 & 44.47 & 0.81 \\
\hline PPNA & Hatula & 40.70 & 2.30 & 1.33 & 63.71 & 1.43 \\
\hline PPNA & Hatula & 26.60 & 2.75 & 1.29 & 26.08 & 0.83 \\
\hline PPNA & Netiv Hagdud & 29.80 & 2.42 & 1.41 & 27.92 & 0.79 \\
\hline PPNA & Netiv Hagdud & 30.00 & 2.51 & 1.11 & 39.03 & 0.66 \\
\hline PPNA & Netiv Hagdud & 5.00 & 1.98 & 1.70 & 65.69 & 0.92 \\
\hline PPNB & Yiftahel & 67.67 & 5.96 & 2.67 & 25.75 & 1.32 \\
\hline PPNB & Yiftahel & 63.69 & 6.00 & 2.07 & 19.04 & 1.61 \\
\hline PPNB & Yiftahel & 65.02 & 5.97 & 2.04 & 16.85 & 1.57 \\
\hline PPNB & Kefar Hahoresh & 61.90 & 4.95 & 2.25 & 31.44 & 1.65 \\
\hline PPNB & Kefar Hahoresh & 30.76 & 7.32 & 3.57 & 38.91 & 1.75 \\
\hline PPNB & Kefar Hahoresh & 35.48 & 7.03 & 4.18 & 25.68 & 1.56 \\
\hline PPNB & Kefar Hahoresh & 36.58 & 5.61 & 2.16 & 18.79 & 1.69 \\
\hline PPNB & Kefar Hahoresh & 50.83 & 5.45 & 2.61 & 17.52 & 1.57 \\
\hline PPNB & Kefar Hahoresh & 22.00 & 5.02 & 3.96 & 52.99 & 2.01 \\
\hline PPNB & Kefar Hahoresh & 24.03 & 5.92 & 3.01 & 26.07 & 1.77 \\
\hline PPNB & Kefar Hahoresh & 35.44 & 5.35 & 2.47 & 30.44 & 1.52 \\
\hline PPNB & Kefar Hahoresh & 51.27 & 4.60 & 2.27 & 20.29 & 1.75 \\
\hline PPNB & Kefar Hahoresh & 59.74 & 3.75 & 2.90 & 17.91 & 1.53 \\
\hline PPNB & Kefar Hahoresh & 47.92 & 4.86 & 2.42 & 20.38 & 1.65 \\
\hline PPNB & Kefar Hahoresh & 59.45 & 4.10 & 2.28 & 42.65 & 1.50 \\
\hline PPNB & Kefar Hahoresh & 37.56 & 3.84 & 1.91 & 23.29 & 1.15 \\
\hline PPNB & Kefar Hahoresh & 23.88 & 5.99 & 2.01 & 29.80 & 1.43 \\
\hline PPNB & Kefar Hahoresh & 65.35 & 4.03 & 2.05 & 28.40 & 1.78 \\
\hline PPNB & Kefar Hahoresh & 35.92 & 5.73 & 3.06 & 33.43 & 1.38 \\
\hline PPNB & Kefar Hahoresh & 26.54 & 5.10 & 2.74 & 38.71 & 1.19 \\
\hline PPNB & Kefar Hahoresh & 45.71 & 5.01 & 2.26 & 21.92 & 1.22 \\
\hline PPNB & Kefar Hahoresh & 59.72 & 4.65 & 2.50 & 21.51 & 2.00 \\
\hline PPNB & Kefar Hahoresh & 65.68 & 6.00 & 2.13 & 19.84 & 1.75 \\
\hline PPNB & Kefar Hahoresh & 58.82 & 4.80 & 2.72 & 27.09 & 1.68 \\
\hline PPNB & Horvat Galil & 37.01 & 5.22 & 3.53 & 26.59 & 1.73 \\
\hline PPNB & Horvat Galil & 58.52 & 4.96 & 2.46 & 18.79 & 2.01 \\
\hline Chalcolithic & Peqiin & 21.27 & 2.50 & 1.52 & 67.09 & 0.67 \\
\hline Chalcolithic & Peqiin & 59.57 & 2.39 & 1.58 & 44.24 & 0.93 \\
\hline Chalcolithic & Peqiin & 47.05 & 2.24 & 1.24 & 37.53 & 0.58 \\
\hline Chalcolithic & Peqiin & 25.00 & 2.44 & 1.04 & 48.11 & 0.84 \\
\hline Chalcolithic & Peqiin & 39.13 & 2.44 & 1.45 & 44.90 & 0.72 \\
\hline Chalcolithic & Peqiin & 37.66 & 2.66 & 1.39 & 29.60 & 0.80 \\
\hline Chalcolithic & Peqiin & 35.29 & 2.56 & 1.46 & 73.72 & 0.78 \\
\hline Chalcolithic & Peqiin & 28.12 & 4.21 & 1.89 & 30.79 & 1.08 \\
\hline Chalcolithic & Peqiin & 26.31 & 2.32 & 1.05 & 32.16 & 0.61 \\
\hline Chalcolithic & Peqiin & 23.25 & 3.10 & 1.93 & 44.55 & 1.11 \\
\hline Chalcolithic & Peqiin & 27.50 & 3.25 & 1.72 & 34.77 & 0.99 \\
\hline Chalcolithic & Peqiin & 54.90 & 2.07 & 1.11 & 64.84 & 0.82 \\
\hline Chalcolithic & Peqiin & 27.77 & 2.79 & 1.81 & 57.97 & 1.17 \\
\hline Chalcolithic & Peqiin & 44.44 & 3.16 & 1.62 & 26.02 & 0.78 \\
\hline Chalcolithic & Peqiin & 42.85 & 2.57 & 1.38 & 53.16 & 0.92 \\
\hline Chalcolithic & Peqiin & 24.00 & 2.87 & 1.33 & 40.44 & 0.77 \\
\hline Chalcolithic & Peqiin & 22.64 & 2.23 & 1.24 & 53.12 & 0.82 \\
\hline Chalcolithic & Peqiin & 30.55 & 2.53 & 1.47 & 33.86 & 0.89 \\
\hline Chalcolithic & Peqiin & 35.71 & 3.72 & 1.85 & 32.12 & 0.94 \\
\hline Chalcolithic & Peqiin & 48.71 & 3.19 & 1.89 & 45.38 & 0.85 \\
\hline Chalcolithic & Peqiin & 26.66 & 2.66 & 2.01 & 55.59 & 1.28 \\
\hline Chalcolithic & Peqiin & 27.27 & 2.98 & 1.48 & 29.07 & 0.77 \\
\hline Chalcolithic & Peqiin & 36.17 & 2.51 & 1.41 & 41.52 & 0.89 \\
\hline Chalcolithic & Peqiin & 55.55 & 2.06 & 1.39 & 47.86 & 0.84 \\
\hline
\end{tabular}

\footnotetext{
${ }^{1}$ Curated at the Sackler School of Medicine, Tel Aviv University.
}

\section{ACKNOWLEDGMENTS}

I thank editor Clark Larsen and three anonymous reviewers for their helpful comments. I thank Baruch Arensburg and Israel Hershkovitz at the Sackler School of Medicine, Tel Aviv University, for allowing access to samples in their care.

\section{LITERATURE CITED}

Agelarakis PA, Palely S, Perth Y, Wink J. 1998. The Chalcolithic burial cave in Ma'avarot, and its paleoanthropological implications. Int J Ost 8:431-443.

Baker G, Jones LHP, Wardrop ID. 1959. Cause of wear in sheeps' teeth. Nature 184:1583-1584. 
Baruch U, Bottema S. 1991. Palynological evidence for climatic change in the Levant ca. 17,000-9,000 BP. In: Bar Yosef O, Valla FR, editors. The Natufian culture in the Levant. Ann Arbor, MI: International Monographs in Prehistory. Archaeological Series 1. p 11-20.

Bar Yosef O. 1991. The archaeology of the Natufian layer at Hayonim Cave. Ann Arbor, MI: International Monographs in Prehistory. Archaeological Series 1. p 81-82.

Bar Yosef O. 1993. Hayonim cave. In: Lewinson-Gilboa A, Aviram J, editors. The new encyclopedia of archaeological excavations in the Holy Land. II. New York: Simon and Schuster. p 590-591.

Bar Yosef O. 1998. The Natufian culture in the Levant: threshold to the origins of agriculture. Evol Anthropol 6:159-77.

Bar Yosef O. 2002. The Upper Palaeolithic revolution. Ann Rev Anthropol 31:363-393.

Bar Yosef O, Gopher A, Tchernov E, Kislev ME. 1991. Netiv Hagdud: an early Neolithic village site in the Jordan Valley. J Field Arch 18:405-424.

Carmi I, Segal D. 1992. Rehovot radiocarbon measurements IV. Radiocarbon 34:115-132.

Cook D, Kirk W. 1995. Rocks and minerals. London: Larousse, plc.

Covert HH, Kay RF. 1981. Dental microwear and diet: implications for determining the feeding behaviors of extinct primates, with a comment on the dietary pattern of Sivapithecus. Am J Phys Anthropol 55:1-36.

Daegling DJ, Grine FE. 1999. Terrestrial foraging and dental microwear in Papio ursinus. Primates 40:559-572.

Dewdney J. 1987. Structures and reliefs; vegetation and soils; landscapes; precipitation. In: Blake G, Dewdney J, Mitchell J, editors. Cambridge atlas of the Middle East and North Africa. Cambridge: Cambridge University Press. p 9-19.

Every RG. 1974. Thegosis in prosimians. In: Martin RD, Walker A, Doyle GA, editors. Prosimian biology. London: Duckworth. p 579-620.

Frankel R, Getzov N, Aviam M, Degani A. 2001. Settlement dynamics and regional diversity in the ancient upper Galilee. IAA Reports 014. Jerusalem: Israel Antiquities Authority.

Gal Z, Smithline H, Shalem D. 1997. Chalcolithic burial cave in Peqi'in. Israel Expl J 47:145-54.

Gal Z, Smithline H, Shalem D. 1999. Finds from the Peqi'in cave. Atiqot 37:1-16.

Garfinkel Y. 1987. Yiftahel: a Neolithic village from the seventh millennium B.C. in lower Galilee, Israel. J Field Archaeol 14: 199-212.

Garfinkel Y. 1993. Yiftahel. In: Lewinson-Gilboa A, Aviram J, editors. The new encyclopaedia of archaeological excavations in the Holy Land, IV. New York: Simon and Schuster. p 1511-1512.

Goldberg P. 1979. Micromorphology of sediments from Hayonim Cave, Israel. Catena 6:167-181.

Goldberg P, Rosen A. 1987. Early Palaeoenvironment of Israel. In: Levy T, editor. Shiqmim I: studies concerning Chalcolithic societies in the northern Negev desert, Israel (1982-1984). Oxford: BAR International Series 356. p 23-33.

Golden J, Levy TE, Hauptmann A. 2001. Recent discoveries concerning Chalcolithic metallurgy at Shiqmim, Israel. J Arch Sci 28:951-963.

Gonen R. 1992. The Chalcolithic period. In: Ben-Tor A, editor (translated by Greenberg A). The archaeology of ancient Israel. New Haven: Yale University Press. p 40-80.

Gopher A. 1997. Horvat Galil-an early PPNB site in the upper Galilee, Israel. Tel Aviv 24:183-222.

Gordon KD. 1982. A study of microwear on chimpanzee molars: implications for dental microwear analysis. Am J Phys Anthropol 59:195-215.

Gordon KD. 1986. Dental microwear analysis to detect human diet. Am J Phys Anthropol 69:206-207.

Goring-Morris N. 2000. The quick and the dead. The social context of aceramic Neolithic mortuary practices as seen from Kfar Hahoresh. In: Kuijt I, editor. Life in Neolithic farming communities. New York: Kluwer Academic. p 103-136.

Grigson C. 1995. Plough and pasture in the early economy of the southern Levant. In: Levy T, editor. The archaeology of society in the Holy Land. London: Leicester Press. p 246-263.
Grine FE, Ungar PS, Teaford MF. 2002. Error rates in dental microwear quantification using scanning electron microscopy. Scanning 24:144-153.

Henry DO. 1989. From foraging to agriculture. The Levant at the end of the Ice Age. Philadelphia: University of Pennsylvania Press.

Hershkovitz IG, Edelson M, Spiers B, Arensburg B, Nadel D, Levi B. 1993. Ohalo II man-unusual findings in the anterior rib cage and shoulder girdle of a 19,000 years-old specimen. Int J Osteo 3:177-188.

Hershkovitz I, Garfinkel Y, Arensburg B. 1986. Neolithic skeletal remains at Yiftahel, area C. Paleorient 12:73-81.

Hershkovitz I, Gopher A. 1988. Human burials from Horvat Galil: a pre-pottery Neolithic site in the upper Galilee, Israel. Paleorient 14:110-125.

Hershkovitz IG, Speirs MS, Frayer D, Nadel D, Wish-Baratz S, Arensburg B. 1995. Ohalo II: a 19,000-year-old skeleton from a water-logged site at the Sea of Galilee, Israel. Am J Phys Anthropol 98:215-234.

Hillman G. 1984. Traditional husbandry and processing of archaic cereals in modern times. I. The glume wheats. Bull Sumer Agric 1:114-152.

Hillman G. 1985. Traditional husbandry and processing of archaic cereals in recent times. II. The free-threshing cereals. Bull Sumer Agri 2:1-31.

Hillman G. 1996. Late Pleistocene changes in wild plant foods available to hunter-gatherers of the northern Fertile Crescent: possible preludes to cereal cultivation. In: Harris DR, editor. The origins and spread of agriculture and pastoralism in Eurasia. London: UCL. p 159-203.

Hopf M. 1983. Jericho plant remains. In: Kenyon KM, Holland TA, editors. Excavations at Jericho, vol 5. Jerusalem: British School of Archaeology in Jerusalem. p 576-621.

Hopf M, Bar Yosef O. 1987. Plant remains from Hayonim Cave. Paleorient 13:117-120.

Horwitz LK, Tchernov E. 1989. Animal exploitation in the Early Bronze Age of the southern Levant: an overview. In: Miroschedji P, editor. L'urbanisation de la Palestine à l'âge du Bronze Ancien. Oxford: BAR International Series 527. p 279-289.

Kahila G, Smith P. 2001. Human remains from Tel Teo'. In: Eisenberg E, Gopher A, Greenberg R, editors. Tel Teo'-a Neolithic, Chalcolithic and early Bronze Age site in the Hula Valley. IAA Reports 13. Jerusalem: Israel Antiquties Authority. p 163-170.

Karmon Y. 1971. Israel. A regional geography. New York: Wiley Interscience.

King T, Andrews P, Bos B. 1999. Effect of taphonomic processes on dental microwear. Am J Phys Anthropol 108:359-373.

Kislev ME. 1985. Early Neolithic horsebean from Yiftah'el, Israel. Science 222:319-320.

Kislev M, Bar-Yosef O, Gopher A. 1986. Early Neolithic domesticated and wild barley from the Netiv Hagdud region in the Jordan valley. Israel J Botany 35:197-201.

Kislev ME, Nadel D, Carmi I. 1992. Epipalaeolithic $(19,000)$ cereal and fruit diet at Ohalo II, Sea of Galilee, Israel. Rev Palaeobot Palynol 73:161-166.

Kislev ME, Simchoni O, Weiss E. 2002. Reconstruction of the landscape, human economy and hut use according to seeds and fruit remains from Ohalo II. In: Nadel D, editor. Ohalo II, a 23,000 year-old fisher-hunter-gatherers camp on the shore of the Sea of Galilee. Haifa: Hecht Museum. p 21-23.

Lalueza C, Pe'rez-Pe'rez A, Turbon D. 1996. Dietary inferences through buccal microwear analysis of Middle and Upper Pleistocene human fossils. Am J Phys Anthropol 100:367-387.

Lechevallier, M., Ronen, A. 1985. Le site natoufien: Khiamien de Hatoula près de Latroun. Israël, fouilles 1980-1982, rapport préliminaire. Jérusalem: Les Chahiers du centre de Recherche Francais de Jérusalem 1.

Lev-Tov N, Gopher A, Smith P. 2003. Dental evidence for dietary practices in the Chalcolithic period: the findings from a burial cave in Peqi'in (northern Israel). Paléorient 29:121-134.

Levy T. 1995. Cult, metallurgy and rank societies-Chalcolithic period ca. 4,500-3,500 BCE. In: Levy T, editor. The archaeology of society in the Holy Land. London: Leicester Press. p 226244 . 
Lucas PW, Peters CR. 2000. Function of postcanine tooth crown shape in mammals. In: Teaford M, Meredith Smith M, Ferguson MWJ, editors. Development, function and evolution of teeth. Cambridge: Cambridge University Press. p 282-289.

Mahoney P. 2003. Human dental microwear in Natufian huntergatherers and pre-pottery Neolithic agriculturalists from northern Israel. Ph.D. dissertation, University of Sheffield.

Mahoney P. 2006a. Dental microwear from Natufian huntergatherers and early Neolithic farmers: comparisons between and within samples. Am J Phys Anthropol 130:308-319.

Mahoney P. 2006b. Microwear and morphology: functional relationships between human dental microwear and the mandible. J Hum Evol 50:452-459.

Mahoney P. 2006c. Inter-tooth and intra-facet dental microwear variation in an archaeological sample of modern humans from the Jordan Valley. Am J Phys Anthropol 129:39-44.

Maier W, Schneck G. 1982. Functional morphology of hominoid dentitions. J Hum Evol 11:693-696.

Martin L. 1994. Hunting and herding in a semi-arid region: an archaeological and ethnological analysis of the faunal remains from the epi-Palaeolithic and Neolithic of the eastern Jordan steppe. Ph.D. dissertation, University of Sheffield.

Molleson T, Jones K. 1991. Dental evidence for dietary change at Abu Hureyra. J Archaeol Sci 18:525-539.

Molleson T, Jones K, Jones S. 1993. Dietary change and the effect of food preparation on microwear patterns in the Late Neolithic at Abu Hureyra, northern Syria. J Hum Evol 24: 455-468.

Nadar Y, Eshed V. 2001. Where are the children? Age-dependent burial practices in Peqi'in. Israel Expl J 51:27-35.

Nadel D. 1990. Ohalo II, a preliminary report. Mitekufat Haeven J Israel Prehist Soc 23:48-59.

Nadel D. 1991. Ohalo II-the third season. Mitekufat Haeven J Israel Prehist Soc 24:158-163.

Nadel D. 2001. Tools on the floor: examples from Ohalo II and Netiv Hagdud. In: Caneva I, Lemorini C, Zampetti D, Biagi P, editors. Beyond tools: redefining the PPN lithic assemblages of the Levant. Berlin: Ex-oriente. p 273-282.

Nadel D. 2003. The Ohalo II flint assemblage and the beginning of the Epipalaeolithic in the Jordan Valley. In: Goring-Morris AN, Belfer-Cohen A, editors. More than meets the eyes: studies on Upper Palaeolithic diversity in the Near East. Oxford: Oxbow Monographs. p 216-229.

Nadel D, Belitzky S, Boaretto E, Carmi I, Heinemeier J, Werker E, Marco S. 2001. New dates from submerged late Pleistocene sediments in the Sea of Galilee, Israel. Radiocarbon 43:11671178 .

Nadel D, Carmi I, Segal D. 1995. Radiocarbon dating of Ohalo II: archaeological and methodological implications. J Arch Sci 22:811-822.

Nadel D, Hershkovitz I. 1991. New subsistence data and human remains from the earliest Levantine Epipalaeolithic. Curr Anthropol 32:631-635.

Nadel D, Weiss O, Simchoni A, Tsatskin A, Danin T, Kislev M. 2004. Stone age hut in Israel yields world's oldest evidence of bedding. Proc Nat Acad Sci 101:6821-6826.

Nadel D, Werker E. 1999. The oldest ever brush hut plant remains from Ohalo II, Jordan Valley, Israel (19 ka BP). Antiquity 73:755-764.

Noy T. 1989. Some aspects of Natufian mortuary behaviour at Nahal Oren. BAR Int Ser 508:53-58.

Noy T. 1993. Nahal Oren. In: Lewinson-Gilboa A, Aviram J, editors. The new encyclopaedia of archaeological excavations in the Holy Land. II. New York: Simon and Schuster. p 1167-1170.

Noy T, Higgs E. 1971. Raqefet cave. Israel Explor J 21:225-226.

Noy T, Legge AJ, Higgs ES. 1973. Recent excavations at Nahal Oren, Israel. Proc Prehist Soc 39:75-99.

Nystrom P, Phillips-Conroy JE, Jolly CJ. 2004. Dental microwear in anubis and hybrid baboons (Papio hamadryas, sensu lato) living in Awash National Park, Ethiopia. Am J Phys Anthropol 125:279-291.

Organ JM, Teaford MF, Larsen CS. 2005. Dietary inferences from dental occlusal Microwear at mission San Luis de Apalachee. Am J Phys Anthropol 128:801-811.
Pastor R. 1993. Dental microwear among prehistoric inhabitants of the Indian subcontinent: a quantitative and comparative analysis. Ph.D. dissertation. Eugene: University of Oregon.

Pe'rez-Pe'rez A, Espurz V, de Castro JMB, de Lumley MA, Turbo'n D. 2003. Non-occlusal dental microwear variability in a sample of Middle and Late Pleistocene human populations from Europe and the Near East. J Hum Evol 44:497-513.

Perrot J. 1960. Excavations at Eynan (Ein Mallaha). Preliminary report on the 1959 season. Israel Explor J 2:14-22.

Perrot J. 1993. Enan. In: Lewinson-Gilboa A, Aviram J, editors. The new encyclopaedia of archaeological excavations in the Holy Land, III. New York: Simon and Schuster. p 389-393.

Piperno DR. 1988. Phytolith analysis: an archaeological and geological perspective. San Diego: Academic Press.

Piperno DR, Weiss E, Holst I, Nadel D. 2004. Processing of wild cereal grains in the Upper Paleolithic revealed by starch grain analysis. Nature 430:670-673.

Pough FH. 1996. Rocks and minerals. New York: Houghton Mifflin.

Puech PF. 1976. Recherche sur le mode d'alimentation des hommes du Paleolithique par l'étude microscopique des couronnes dentaires. In: de Lumley H, editor. La Préhistoire Française I. Centre National de la Recherche Scientifique. p 708709.

Rabinovich R. 2002. The mammal bones: food, environment and tools. In: Nadel D, editor. Ohalo II, a 23,000-year-old fisherhunter-gatherers camp on the shore of the Sea of Galilee. Haifa: Hecht Museum. p 24-27.

Rensberger JM. 1978. Scanning electron microscopy of wear and occlusal events in some small herbivores. In: Butler PM, Joysey KA, editors. Development, function and evolution of teeth. London: Academic Press. p 415-437.

Rensberger JM. 2000. Pathways to functional differentiation in mammalian enamel. In: Teaford M, Meredith Smith M, Ferguson MWJ, editors. Development, function and evolution of teeth. Cambridge: Cambridge University Press. p 252-268.

Ronen A, Lechevallier M. 1993. Hatula. In: Lewinson-Gilboa A, Aviram J, editors. The new encyclopaedia of archaeological excavations in the Holy Land, I. New York: Simon and Schuster. p $120-122$

Ryan A. 1979. Wear striation direction on primate teeth. Am J Phys Anthropol 50:155-168.

Schmidt CW. 2001. Dental microwear evidence for a dietary shift between two nonmaize-reliant prehistoric human populations from Indiana. Am J Phys Anthropol 114:139-145.

Shalev S. 1994. Changes in metal from the Chalcolithic period to the early Bronze Age in Israel and Jordan. Antiquity 68:630-637.

Simmons T, Nadel D. 1998. The avifauna of the early Epipalaeolithic site of Ohalo II (19,400 B.P.), Israel: species diversity, habitat and seasonality. Int J Osteo 8:79-96.

Smith P, Sabari P. 1995. The Chalcolithic remains from Horvat Hor. Israel Expl J 45:128-135.

Steckelis M, Yizraely T. 1963. Excavations at Nahal Oren. Preliminary report. Israel Explor J 13:1-12.

Tabachnick BG, Fidell L. 2001. Using multivariate statistics, 4th ed. Needham Heights, MA: Allyn and Bacon.

Teaford MF. 1988. Scanning electron microscope diagnosis of wear patterns versus artifacts on fossil teeth. Scan Microsc 2: 1167-1175.

Teaford MF. 1993. Dental microwear and diet in extant and extinct Theropithecus: preliminary analyses. In: Jablonski NG, editor. Theropithecus: the life and death of a primate genus. Cambridge: Cambridge University Press. p 331-349.

Teaford MF, Larsen CS, Pastor RF, Noble VE. 2001. Pits and scratches. Microscopic evidence of tooth use and masticatory behaviour in La Florida. In: Larsen CS, editor. Bioarchaeology of La Florida: human biology in the northern frontier New Spain. Gainesville: University Press of Florida. p 82112.

Teaford MF, Lytle JD. 1996. Brief communication: diet-induced changes in rates of human tooth microwear. A case study involving stone-ground maize. Am J Phys Anthropol 100:143-147. 
Teaford MF, Oyen OJ. 1989. Differences in the rate of molar wear between monkeys raised on different diets. J Dent Res 6:1513-1518.

Teaford MF, Runestad JA. 1992. Dental micowear and diet in Venezualan primates. Am J Phys Anthropol 88:347-364.

Teaford MF, Walker A. 1983. Dental microwear in adult and still born guinea pigs (Cavia porcellus). Arch Oral Biol 28: 1077-1081.

Teaford MF, Walker A. 1984. Quantitative differences in dental microwear between primate species with different diets and a comment on the presumed diet of Sivapithecus. Am J Phys Anthropol 64:191-200.

Tsatskin A, Nadel D. 2003. Formation processes at the Ohalo II submerged prehistoric campsite, Israel, inferred from soil micromorphology and magnetic susceptibility studies. Geoarchaeology 18:409-432.

Ungar PS. 1992. Feeding behavior and dental microwear in Sumatran anthropoids. Ph.D. dissertation, State University of New York at Stony Brook.

Ungar PS. 1994. Incisor microwear of Sumatran anthropoid primates. Am J Phys Anthropol 94:339-363.

Ungar PS. 1997. Microware 3. http://comp.uark.edu/_pungar/

Ungar PS, Grine FE, Teaford MF, El Zaatari S. 2006. Dental microwear and diets of African early Homo. J Hum Evol 50:78-95.

Ungar PS, Spencer MA. 1999. Incisor microwear, diet, and tooth use in three Amerindian populations. Am J Phys Anthropol 109:387-396.

Valla FR, Khalaily H, Samuelian N, Bocquentin F, Delange C, Valentin B, Plisson H, Rabinovitch R, Belfer-Cohen A. 1998. Le Natoufien final et les nouvelles fouilles à Mallaha (Eynan), Israel, AQ16, 1996-1997. p 105-176.

Van Valkenburgh B, Teaford MF, Walker A. 1990. Molar microwear and diet in large carnivores: inferences concerning diet in the sabretooth cat, Smilodon fatalis. J Zool London 222:319-340.

Van Zeist W, Bakker-Heeres JA. 1984. Archaeological studies in the Levant 1. Neolithic sites in the Damascus basin: Aswad, Ghoraife and Ramad. Palaeohistoria 24:165-256.
Waddle DM. 1988. Diet of early Homo erectus in Africa: a quantitative microwear analysis. Am J Phys Anthropol 75: 284.

Walker A, Hoeck HN, Perez L. 1978. Microwear of mammalian teeth as an indicator of diet. Science 201:908-910.

Weiss E, Kislev ME, Simchoni O, Nadel D. 2005. Small-grained wild grasses as staple food at the 23,000 year-old site of Ohalo II. Israel Econom Bot 588:125-134.

Weiss E, Wetterstrom W, Nadel D, Bar-Yosef O. 2004. The broad spectrum revisited: evidence from plant remains. Proc Nat Acad Sci USA 101:9551-555.

Willcox G. 1998. Archaeobotanical evidence for the beginnings of agriculture in southwest Asia. In: Damania AB, Valkoun J, Willcox G, Qualset CO, editors. The origins of agriculture and crop domestication. Aleppo, Syria: ICARDA. p 2538.

Willcox G. 1999. Agarian change and the beginnings of cultivation in the Near East: evidence from wild progenitors, experimental cultivation and archaeobotanical data. In: Godsen C, Hather J, editors. The prehistory of food: appetites for change. London: Routledge. p 478-500.

Wright K. 1993. Early Holocene ground stone assemblages in the Levant. Levant 25:93-111.

Zagerson T, Smith P. 2002. The human remains from the Kissufim road. In: Goren Y, Fabian P, editors. The Chalcolithic mortuary site at Kissufim road, Israel. IAA Reports 16. Jerusalem: Israel Antiquities Authority. p 57-65.

Zar JH. 1999. Biostatistical analysis, 4th ed. New Jersey: Prentice Hall.

Zohary D, Hopf M. 1993. Domestication of plants in the Old World. Oxford: Oxford Science.

Zohary D, Spiegel-Roy P. 1975. Beginnings of fruit growing in the Old World. Science 187:318-326.

Zohar I. 2002. Fish and fishing at Ohalo II. In: Nadel D. Ohalo II, a 23,000-year-old fisher- hunter-gatherers camp on the shore of the Sea of Galilee. Haifa: Hecht Museum. p 28-31. 